\title{
Comparison of ELISA antigen preparations alone or in combination for serodiagnosing Helicobacter pylori infections
}

\author{
A M Hirschl, B J Rathbone, J I Wyatt, J Berger, M L Rotter
}

\begin{abstract}
The immunoglobulin $G$ antibody response to Helicobacter pylori was assessed in 78 patients with non-ulcer dyspepsia using five different antigen preparations. All patients were endoscoped and biopsied. The $H$ pylori state was determined histologically on at least two endoscopic biopsy specimens using a modified Giemsa stain. The ultracentrifuged cell sonicate, acid glycine extract, and 120 kilodalton protein antigens were specific in diagnosing infection (95-98\%), but had only moderate sensitivity (70-84\%). By mixing either of the two complex antigens with the 120 kilodalton protein, the sensitivity of the test was increased to $97 \%$ without affecting the high specificity. The combination of ultracentrifuged sonicate or acid glycine extract with the 120 kilodalton protein therefore seems to be superior to the individual antigen preparations and is particularly suitable for the serodiagnosis of $\boldsymbol{H}$ pylori infection.
\end{abstract}

The strong association between Helicobacter pylori colonisation and chronic antral gastritis and peptic ulceration is widely recognised. ${ }^{1-3}$ An increasing body of evidence suggests that the organism has a role in the pathogenesis of chronic gastritis, although exactly how is unclear. Diagnosis of colonisation usually relies on culture of biopsy specimen, histology, or urease testing. Such techniques are invasive, but non-invasive techniques such as urea breath tests and serology have been used. The former technique, using either ${ }^{13} \mathrm{C}$ or ${ }^{14} \mathrm{C}$, is generally time consuming and relatively expensive compared with the latter. ${ }^{4-6}$ Several enzyme linked immunosorbent assays (ELISA) have been described, but the tests only partially meet the ideal of very high sensitivity and specificity. Little work has been carried out that directly compares the different techniques. The aim of this study was to compare three different antigen preparations and their combination in terms of sensitivity and specificity for diagnosing $H$ pylori colonisation.

\section{Methods}

Sera were collected from 78 consecutive dyspeptic patients (excluding those with ulceration at endoscopy) attending an endoscopy clinic. Antral and body mucosal biopsy specimens were taken at endoscopy. The sera were stored at $-20^{\circ} \mathrm{C}$ before assay.

The gastric biopsy specimens were formalin fixed and routinely processed. Sections stained with haematoxyline and eosin were used to assess the mucosal inflammation and a modified Giemsa stain was used to diagnose $H$ pylori colonisation. ${ }^{7}$ The sections were assessed by a single pathologist who was unaware of the clinical diagnosis.

$H$ pylori NCTC 11637 was used throughout for all antigen preparations. The strain was cultivated on Mueller Hinton agar (Oxoid), which was supplemented with $5 \%$ defibrinated sheep blood, for 72 hours at $37^{\circ} \mathrm{C}$ under microaerophilic conditions. Bacteria were harvested, resuspended, and washed (three times) in phosphate buffered saline (PBS); $0.01 \mathrm{M}, \mathrm{pH} 7.2$. The resulting pellet was immediately processed or frozen at $-25^{\circ} \mathrm{C}$.

The ultracentrifuged cell sonicate was prepared as follows: The washed strain was inactivated at $60^{\circ} \mathrm{C}$ for 15 minutes and then sonicated for 10 seconds in a Branson ultrasonifier (microtip, position 5, 40\% pulsed). The cell sonicate was then ultracentrifuged (100000 $\times g$ for 60 minutes) in a fixed angle rotor (Centrikon-T 2060, Kontron Instruments) and the supernatant stored at $-25^{\circ} \mathrm{C}$.

To prepare an acid glycine extract, to every $100 \mathrm{mg}$ (net weight) of bacterial cell mass $2.5 \mathrm{ml}$ of glycine buffer $(0.2 \mathrm{M}, \mathrm{pH} 2 \cdot 2)$ were added; this suspension was gently mixed for 20 minutes at room temperature and centrifuged $\left(1800 \times g\right.$ for 15 minutes at $\left.4^{\circ} \mathrm{C}\right)$. The supernatant was neutralised with $\mathrm{NaOH}(1.0 \mathrm{M})$ to $\mathrm{pH} 7.0$ and dialysed against distilled water (24 hours at $4^{\circ} \mathrm{C}$ ). Insoluble particles were spun down and the supernatant stored at $-25^{\circ} \mathrm{C}$.

The high molecular weight 120 kilodalton protein was prepared by electroelution from sodium dodecyl sulphate polyacrylamide gels as described previously. ${ }^{8}$

All antigen preparations were diluted in sodium carbonate/bicarbonate buffer (0.05, $\mathrm{pH} \mathrm{9.6).} \mathrm{A} \mathrm{protein} \mathrm{concentration} \mathrm{of} 4 \mathrm{mg} / \mathrm{l}$, found to be optimal in previous experiments, was used throughout. ${ }^{8}$ For mixtures of the ultracentrifuged cell sonicate or the acid glycine extract with the 120 kilodalton protein antigen, a concentration of $4 \mathrm{mg} / \mathrm{l}$ of each constituent was found to be optimal by checkerboard titration. Before each experiment round bottomed microtitre plates were coated with $0.1 \mathrm{ml} /$ well of antigen preparation and then incubated for $16-18$ hours at $4^{\circ} \mathrm{C}$. To 
Comparison of $H$ pylori antibody titres in sera from patients with $(\mathbf{\Delta})$ and without $(\triangle) H$ pylori associated gastritis using three antigen preparations (UCS = ultracentrifuged cell sonicate, $A G E=$ acid glycine extract,

P120 = protein with molecular weight of 120 kilodaltons and mixtures of them $(\backsim=$ mean titre of sera from $H$ pylori

negative patients + 3SD).

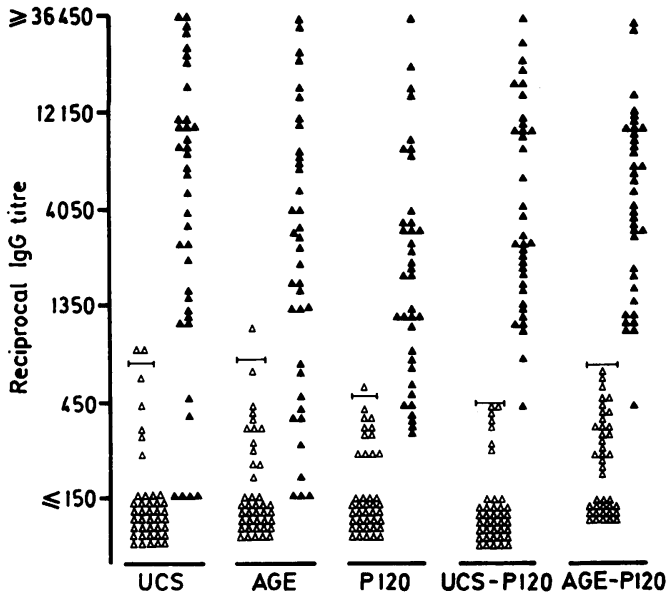

detect class specific antibodies peroxidase conjugated anti-human IgG (goat; Fc specific; Nordic) was used at a dilution of $1 / 1000$. Patients' sera and conjugate were diluted in phosphate buffer ( $\mathrm{pH} \mathrm{7.4)}$ supplemented with $2{ }_{0}^{\circ}$ Tween- 20 and $1 \%$ bovine serum albumin; the plates were rinsed with phosphate buffer (pH 7.4) supplemented with $0.05 \%$ Tween 20 . A substrate of $40 \mathrm{mg}$ o-phenylene-diamine dihydrochloride (Sigma) in $100 \mathrm{ml}$ phosphate/ citrate buffer ( $\mathrm{pH} 5 \cdot 0$ ) with added $\mathrm{H}_{2} \mathrm{O}_{2}(30 \%$; $0.04 \mathrm{ml}$ ) was used. Coated plates were filled with $0 \cdot 1 \mathrm{ml} /$ well of $\log ^{3}$ dilutions of the test sera, starting from $1: 150$, and incubated at $37^{\circ} \mathrm{C}$ for two hours covered with a lid. After three washings plates were reincubated $\left(37^{\circ} \mathrm{C}\right.$ for two hours) with conjugate $(0.1 \mathrm{ml} /$ well $)$. After another three washings $0.1 \mathrm{ml}$ of substrate solution was added to each well and the plates were incubated at room temperature in the dark for 15 minutes. The enzymatic reaction was stopped by adding $0.05 \mathrm{ml} /$ well sulphuric acid $(2.5 \mathrm{M})$ and the plates were read by optical density (OD) measurements at $492 \mathrm{~nm}$.

In an $x$-y diagram the $O D$ values recovered from the ELISA readings were plotted against the $\log ^{3}$ serum dilutions for each antigen and

Table 1 Comparison of ELISA results of sera from patients with histologically verified $H$ pylori-associated gastritis and negative ELISA titres in at least one antigen preparation

\begin{tabular}{|c|c|c|c|c|c|c|c|c|c|c|c|c|c|c|c|}
\hline \multirow[b]{2}{*}{ Antigen } & \multicolumn{15}{|c|}{ Serum No } \\
\hline & 1 & 2 & 3 & 11 & 22 & 32 & 35 & 44 & 49 & 50 & 53 & 61 & 66 & 72 & 76 \\
\hline $\begin{array}{l}\text { UCS } \\
\text { AGE }\end{array}$ & + & - & + & \pm & + & + & + & - & - & + & - & - & + & + & - \\
\hline $\begin{array}{l}\text { AGE } \\
\text { P120 }\end{array}$ & $\bar{t}$ & $\bar{t}$ & - & $\bar{t}$ & $\begin{array}{l}+ \\
-\end{array}$ & + & $\bar{t}$ & $\bar{t}$ & - & \pm & $\bar{t}$ & $\bar{t}$ & $\bar{t}$ & \pm & $\bar{t}$ \\
\hline $\begin{array}{l}\text { P120 } \\
\text { UCS }+ \text { P120 }\end{array}$ & $\begin{array}{l}+ \\
+\end{array}$ & & $\bar{t}$ & $\begin{array}{l}t \\
t\end{array}$ & $\bar{t}$ & $\bar{t}$ & $\begin{array}{l}+ \\
+\end{array}$ & $\begin{array}{l}t \\
t\end{array}$ & - & $\bar{t}$ & $\stackrel{+}{+}$ & $\stackrel{+}{+}$ & $\stackrel{+}{+}$ & $\bar{t}$ & $\begin{array}{l}+ \\
+\end{array}$ \\
\hline $\begin{array}{l}\mathrm{UCS}+\mathrm{P} 120 \\
\mathrm{AGE}+\mathrm{P} 120\end{array}$ & $\begin{array}{l}+ \\
+\end{array}$ & $\begin{array}{l}+ \\
+\end{array}$ & + & $\begin{array}{l}+ \\
+\end{array}$ & $\begin{array}{l}+ \\
+\end{array}$ & $\begin{array}{l}+ \\
+\end{array}$ & $\begin{array}{l}+ \\
+\end{array}$ & $\begin{array}{l}+ \\
+\end{array}$ & - & $\begin{array}{l}+ \\
+\end{array}$ & $\begin{array}{l}+ \\
+\end{array}$ & $\begin{array}{l}+ \\
+\end{array}$ & $\begin{array}{l}t \\
t\end{array}$ & $\begin{array}{l}t \\
t\end{array}$ & $\begin{array}{l}+ \\
+\end{array}$ \\
\hline
\end{tabular}

UCS $=$ ultracentrifuged cell sonicate; AGE $=$ acid glycine extract; P120 $=120$ kilodalton protein.

Table 2 Specificity (\%), sensitivity (\%), and predictive values (\%) of $\mathrm{H}$ pyloriIgG ELISAs with different antigen preparations

\begin{tabular}{|c|c|c|c|c|c|}
\hline & \multicolumn{5}{|c|}{ Antigen } \\
\hline & UCS & $A G E$ & $P 120$ & $U C S+P 120$ & $A G E+P 120$ \\
\hline $\begin{array}{l}\text { Sensitivity } \\
\text { Specificity } \\
\text { Positive predictive value } \\
\text { Negative predictive value }\end{array}$ & $\begin{array}{l}84 \\
95 \\
94 \\
87\end{array}$ & $\begin{array}{l}70 \\
98 \\
96 \\
78\end{array}$ & $\begin{array}{l}84 \\
98 \\
97 \\
87\end{array}$ & $\begin{array}{r}97 \\
100 \\
100 \\
98\end{array}$ & $\begin{array}{r}97 \\
100 \\
100 \\
98\end{array}$ \\
\hline
\end{tabular}

$\overline{\mathrm{UCS}}=$ ultracentrifuged cell sonicate; $\mathrm{AGE}=$ acid glycine extract; P120 $=120$ kilodalton protein. serum used. For each individual patient serum, a titre was calculated by projecting the intersection point of the serum dilution curve with the horizontal line originating in the point $\mathrm{OD}=1.0$ on the $\mathrm{x}$ axis. This serum dilution value can be read graphically.

The sensitivity, specificity, positive and negative predictive values were calculated. "False positive" were titres of sera from $H$ pylori negative patients that exceeded the mean titre of all sera from negative patients by more than 3 standard deviations. "False negative" were defined as the results of sera from patients known to be infected, with titres lying within this range of threefold standard deviation.

\section{Results}

The individual reciprocal antibody titres using the different antigen preparations in the $H$ pylori positive and negative patients are shown in the figure. The ultracentrifuged cell sonicate, acid-glycine extract, and 120 kilodalton protein antigens resulted in two, one, and one false positive results, respectively, and six, 11, and six false negative results, respectively. In table 1 the outcome of the tests with the 15 sera giving discrepant results with the various antigens is presented. With the exception of serum 49 , all sera giving false negative results with one or two antigens reacted with at least one of the other antigens. Consequently, using a mixture of the 120 kilodalton protein with an ultracentrifuged cell sonicate or acid-glycine extract, rendered all but one serum sample positive by ELISA. The combined use of these antigens thus increased the sensitivity of the test (significantly so in the case of the acidglycine extract and 120 kilodalton protein; $\mathrm{p}=0.01$; McNemar test) and improved the negative predictive value without affecting the specificity (table 2 ).

\section{Discussion}

The nature of antigens commonly used for serodiagnosis of $H$ pylori infection may be classified into three categories: (i) whole cell antigens and ultrasonicates of them; (ii) partially purified; and (iii) highly purified antigens.

Whole cell antigens and their sonicates possess the theoretical advantage of exposing a maximum number of surface antigens. This seems to be desirable in view of the extremely variable immune response to $H$ pylori, ${ }^{9}$ but it also increases the risk of non-specific binding of immunoglobulins and of cross reaction with Campylobacter species. ${ }^{10}$ Indeed, there are reports of unacceptably high numbers of false positive results of ELISAs with a specificity of only $73-78 \%$ when a whole cell antigen is used $^{11-13}$; the sensitivity, however, ranged well above $90 \%$ when using this type of antigen.

Ultrasonicated cells seem to offer a somewhat better specificity when used as an antigen. In IgG or IgA ELISAs Perez-Perez et al found specificity values of $90 \%$ and $80 \%$, respectively, and of $95 \%$ when combining the results of both tests. ${ }^{14}$ With a similarly prepared 
antigen-that is, a shortly pelleted ultrasonicate, we have found a specificity of $98 \%$ (but a sensitivity of only $76 \%$ ) when testing the sera of this study (unpublished data). These numbers are greatly influenced by the cut off value chosen for "positive" and negative". Loffeld $e t$ al used two cut off values in their test and found positive and negative predictive values of $100 \%$ for both. ${ }^{6}$ The results of nearly $20 \%$ of sera examined were, however, not in the interpretable range.

Among the partially purified antigens the most commonly used are an ultracentrifuged cell sonicate, an acid glycine extract, and a crude urease preparation. As can be seen from our results the two former types of preparation give an excellent specificity but insufficient sensitivity. The choice of the cut-off value, which in this study was fixed relatively high (mean titre of negative sera $+3 S D$ ), has an important role in determining the sensitivity and specificity values. Goodwin et al reported the sensitivity and specificity of their test as $81 \%$ and $97 \%$, respectively, if they fixed the cut off at 300 ELISA units, but $99 \%$ and $78 \%$ at 150 ELISA units. ${ }^{15}$ For an ELISA with an acid glycine extract antigen, Newell and Stacey tested more than 600 sera and found the sensitivity and specificity to be $92 \%$ and $89 \%$, respectively. ${ }^{16}$ Compared with other types of preparation, a crude urease preparation does not seem to offer special advantages; in contrast, the proportion of false positive results is relatively high. ${ }^{16}$ This fact, however, was thought by Dent $e t$ al to originate from a failure to show $H$ pylori in bacteriological culture or histological examination rather than from a faulty serological test. ${ }^{17}$

Generally, highly purified antigens such as purified urease, ${ }^{16} \mathrm{~N}$-acethylneuraminyllactose binding haemagglutinin, ${ }^{18}$ and the 120 kilodalton protein are very specific but have poor sensitivity. Yet, for the latter antigen the test sensitivity was not lower than that of both of the more complex antigens. One problem with the 120 kilodalton protein is that it is not demonstrable in all strains of $H$ pyori ${ }^{19}$

The most important finding of this study is the fact that the three antigens studied, although giving only suboptimal sensitivity when used alone, produce optimal sensitivity and specificity when used in combination. Coating microtitre plates with the antigen mixture is simple and the results observed with the combination are those expected from the results of the antigens alone. Only one serum sample was found to be a false negative with each of the antigens and consequently also with their mixtures. Perhaps the patient was infec- ted with a less common variant of $H$ pylori so that his immune response remained undetected with antigens prepared from only one isolate.

In summary we conclude that the combination of a prepurified complex antigen of $H$ pylori with its 120 kilodalton protein results in an antigen rendering the ELISA highly specific and very sensitive. This antigen combination thus seems well suited for accurate diagnosis of $H$ pylori infection. 1 Dixon MF. Campylobacter pylori and chronic gastritis. In:
Rathbone BJ, Heatley RV, eds. Campylobacter pylori and gastroduodenal disease. Oxford: Blackwell Scientific Publications, 1989:106-16.

2 Wyatt JI. Campylobacter pylori, duodenitis and duodenal ulceration. In: Rathbone BJ, Heatley RV, eds. Campylobacter pylori and gastroduodenal disease.
Blackwell Scientific Publications, 1989:117-24.

3 O'Connor HJ, Axon ATR. Campylobacter pylori, gastric ulceration and the post-operative stomach. In: Rathbone $\mathrm{BJ}$, Heatley RV, eds. Campylobacter pylori and gastroduodenal disease. Oxford: Blackwell Scientific Publications, 1989:125-38.

4 Newell DG, Stacey AR. The serology of Campylobacter pylori infections. In: Rathbone BJ, Heatley RV, eds Campylobacter pylori and gastroduodenal disease. Oxford: Blackwell Scientific Publications, 1989:74-82.

5 Newell DG, Rathbone BJ. The serodiagnosis of Campylobacter pylori infection. Serodiagnostic Immunotherapy 1989;3:1-6.

6 Loffeld RJLF, Stobberingh E, Flendrig JA, Van Spreeuwel JP, Arends JW. Diagnostic value of an immunoassay to detect anti Campylobacter pylori ontibodies in non ulcer

7 Gray SF, Wyatt JI, Rathbone BJ. Simplified techniques for identifying Campylobacter pyloridis. J Clin Pathol 1986;39:1279-80.

8 Hirschl AM, Pletschette M, Hirschl MH, Berger J, Stanek $\mathrm{G}$, Rotter ML. Comparison of different antigen preparations in an evaluation of the immune response to Campylobacter pylori. Eur J Clin Microbiol Infect Dis 1988;7:570-5.

9 Von Wulffen H, Grote HJ, Gatermann S, Löning T, Berger $\mathrm{B}$, Buhl C. Immunoblot analysis of immune response to Campylobacter pylori and its clinical associations. J Clin Pathol 1988;41:653-9.

10 Newell DG. Identification of outer membrane proteins of Campylobacter pyloridis and antigenic cross reactivity between Campylobacter pyloridis and Campylobacter jetween Campylobacter pyloridis and

11 Morris A, Nicholson G, Lloyd G, Haines D, Rogers A, Taylor D. Seroepidemiology of Campylobacter pyloridis. NZ Med J 1986;99:657-9.

12 Schaber E, Umlauft F, Stöffler G, Aigner F, Paulweber B, Sandhofer F. Indirect immunofluorescence test and enzyme-linked immunosorbent assay for detection of Campylobacter pylori. J Clin Microbiol 1989;27:327-30.

13 Musgrove C, Bolton FJ, Krypczyk AM, et al. Campylobacter pylori: clinical, histological, and serological studies.J Clin Pathol 1988;41:1316-21.

14 Perez-Perez GI, Dworkin BM, Chodos JE, Blaser MJ. Campylobacter pylori antibodies in humans. Ann Intern Med 1988;109:11-17.

15 Goodwin CS, Blincow E, Petersen G, et al. Enzyme-linked immunosorbent assay for Campylobacter pyloridis: immunosorbent assay for Campylobacter pyloridis: 'correlation with presence of Campylobacter pylorid

16 Newell DG, Stacey AR. Antigens for the serodiagnosis of Campylobacter pylori infection. Gastroenterol Clin Biol 1989;13:37B-41B.

17 Dent JC, McNulty CAM, Uff JS, Gear MWL, Wilkinson SP. Campylobacter pylori urease: a new serological test. Lancet 1988;i:1002.

18 Evans DJ, Evans DG, Smith VE, Graham DY. Serum antibody responses to the $\mathrm{N}$-acethylneuraminyllactosebinding hemagglutinin of Campylobacter pylori. Infect Immun 1989;57:664-7.

19 Jacobs E, Apel I, Kist M, Bredt W. Antibody response of patients against a $120 \mathrm{KDs}$ surface protein of Campylobacter pylori. Zbl Bakt Hyg A 1988;268:271-6. 